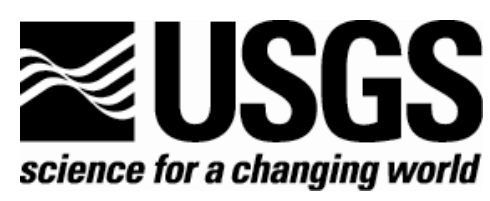

\title{
Eolian Dust and the Origin of Sedimentary Chert
}

By C. Blaine Cecil

\section{Open-File Report 2004-1098}

U.S. Department of the Interior

U.S. Geological Survey 


\title{
U.S. Department of the Interior
}

\author{
Gale A. Norton, Secretary
}

\section{U.S. Geological Survey \\ Charles G. Groat, Director}

\section{U.S. Geological Survey, Reston, Virginia 20192}

2004

For product and ordering information:

World Wide Web: http://www.usgs.gov/pubprod

Telephone: 1-888-ASK-USGS

For more information on the USGS - the Federal source for science about the Earth, its natural and living resources, natural hazards, and the environment:

World Wide Web: http://www.usgs.gov

Telephone: 1-888-ASK-USGS

Although this report is in the public domain, permission must be secured from the individual copyright owners to reproduce any copyrighted material contained within this report. 


\title{
Eolian Dust and the Origin of Sedimentary
} Chert

\author{
By C. Blaine Cecil \\ U.S. Geological Survey, Reston, VA 20192, USA \\ email: bcecil@usgs.gov \\ key words: eolian, dust, silica, sedimentary chert
}

\begin{abstract}
This paper proposes an alternative model for the primary source of silica contained in bedded sedimentary chert. The proposed model is derived from three principal observations as follows: (1) eolian processes in warm-arid climates produce copious amounts of highly reactive fine-grained quartz particles (dust), (2) eolian processes in warm-arid climates export enormous quantities of quartzose dust to marine environments, and (3) bedded sedimentary cherts generally occur in marine strata that were deposited in warm-arid paleoclimates where dust was a potential source of silica. An empirical integration of these observations suggests that eolian dust best explains both the primary and predominant source of silica for most bedded sedimentary cherts.
\end{abstract}

\section{The Chert Problem Revisited}

The enigmatic source of silica contained in bedded sedimentary cherts is generally inferred from one or more of the following processes: (1) biotic extraction of silica from seawater, (2) silica derived from dissolution of volcanic ash, (3) silica expelled from submarine volcanic vents, or (4) silica deposited by post-burial fluid flow (see reviews by Hesse 1990; Carozzi 1993; and Knauth 1994). It is generally difficult, however, to account for either the temporal and spatial distribution of bedded cherts, or the enormous quantities of silica contained in massive bedded sedimentary cherts by these processes. In particular, biologically mitigated chert formation is especially intractable for Precambrian cherts that were deposited prior to the evolution of silica-secreting organisms (Knauth, 1994).

Except for incidental comments (e.g., Haught 1956; Carozzi 1993; Edgar and Cecil 2003), dust has not been proposed as the primary source of silica for bedded cherts even though paleogeographic and paleoclimate reconstructions (e.g., Scotese 1998) indicate that the vast majority of Phanerozoic bedded sedimentary cherts are associated with strata that were deposited in or near warm-arid to semiarid paleoclimates. This paper, therefore, discusses quartzose dust as the primary source of silica for chert, and presents selected examples of the empirical relations among chert occurrences and warm-arid paleoclimates. The postulate developed herein suggests that quartzose eolian dust best accounts for the primary and predominant source of silica contained in most bedded sedimentary cherts. 


\section{Fine-Grained Quartz Particles and the Origin of Chert}

\section{The chemistry of fine-grained quartz particles}

The chemistry of dust-size particles of quartz ( $\# 60 \Phi \mathrm{m}$ ) derived from air abrasion provides important clues for dust as a cogent source of silica for chert. The silt-size and smaller particles ( $\# 60$ Фm) of quartz produced by abrasion (Whalley and others, 1987; Wright 2001) are very reactive, in part because of their very small size, high angularity, and the resultant large surface areas and high surface energies. In addition, the surface of abraded quartz particles is composed of a 0.1-Фm-thick layer of amorphous silica consisting predominantly of silanol groups (Iller 1955; Kronenberg 1994). Because amorphous silica is an order of magnitude more soluble than quartz (e.g., Iller 1955), the amorphous layer becomes a volumetrically significant source of dissolved silica in particles of fine-grained quartz because of the small size and large surface area.

In addition to the amorphous surface layer, the crystal lattice of abraded quartz particles is disordered to depths of $5 \Phi \mathrm{m}$ and perhaps to depths of 50 to $100 \Phi \mathrm{m}$ (Iller 1955) (Fig. 1). Data on the enthalpy of solution of quartz particles derived from mechanical abrasion in air indicate that the entire lattice of quartz particles less than 30 Фm (\#medium silt) is disordered and metastable with respect to the ordered core of coarser quartz particles (Hemingway and Nitkiewicz 1995). These data suggest that structural disorder induced by air abrasion is significant to depths of at least $15 \Phi \mathrm{m}$. As a result of the amorphous outer layer and lattice disorder (to depths of $15 \Phi \mathrm{m}$ ), the \#-30-Фm-size fraction of quartz dust is metastable and relatively soluble. Additionally, water extraction of attrition fragments of quartz derived from air abrasion experiments by Whalley and others, (1987) resulted in concentrations of dissolved silica that ranged from 300 to $1600 \mathrm{ppm}(\Phi \mathrm{g} / \mathrm{l})$. They suggested (p. 137) that equally high concentrations of silica in solution could be derived from naturally abraded sand grains. Furthermore, experiments have shown that fine-grained quartz is highly susceptible to pressure solution and diagenetic alteration (Renton and others, 1969). The aforementioned chemical characteristics of fine quartz suggest that quartz dust is highly reactive.

\section{Particle sizes of silica in dust and chert}

In a thorough review of silica in chert, Knauth (1994) pointed out that most cherts are predominantly composed of $\alpha$-quartz in the form of granular microcrystalline quartz and megaquartz, with minor amounts of fibrous silica. According to Knauth (1994), silica particles in chert range in size from less than 1 to 60 $\mu \mathrm{m}$, but they are generally on the order of 8-10 $\mu \mathrm{m}$. The particle sizes of silica particles in chert are remarkably similar to the particle sizes of quartz in aerosols (airborne dust) derived from warm deserts. Furthermore, partial or total diagenetic dissolution of the metastable outer layers of air-abraded $\alpha$-quartz particles in dust would significantly diminish the size of detrital particles and also change particle shape (Fig. 1).

Conclusions.-- The thermodynamic data of Hemingway and Nitkiewicz (1995), the amounts of dissolved silica derived from experimentally abraded quartz particles (Whalley and others, 1987), and the susceptibility of fine-quartz to pressure solution (Renton and others, 1969) suggest that quartzose dust is very reactive and highly susceptible to diagenetic alteration. Following dissolution of the metastable outer layers, the residual inter core approximates the size of much of the megaquartz found in chert (Fig. 1). Furthermore, the thermodynamic data indicate that the microquartz and fibrous silica in chert may be the product of precipitation of silica from solutions that were supersaturated with respect to $\alpha$-megaquartz. Diagenesis of quartzose dust, therefore, may best explain the source of silica and the petrology of most bedded cherts. 


\section{Potential Sources of Silica for Chert in Marine Environments}

\section{Export of dust from warm-arid environments}

Dust as a precursor for chert is likely restricted to aerosols derived from warm-arid deserts where finegrained quartz is the predominant mineral component. Significant quantities of quartzose eolian dust are exported from modern terrestrial warm-arid environments. For example, 130 to 760 million tonnes of dust are blown from the Sahara Desert each year (Wright 2001; Goudie 2003). The Saharan dust is composed predominantly of fine-grained quartz with minor amounts of carbonates, feldspars, and clay minerals (e.g., Molinaroli 1996), unlike the heterogeneous composition of dust in cold-climate deserts. Rates of dust deposition in modern warm deserts range from 50 to 200 tonnes $\mathrm{km}^{-2} \mathrm{yr}^{-1}$ (summarized in Pye and Tsoar 1987), which could result in accumulation rates that range from 2 to $7.510^{-3} \mathrm{~cm} / \mathrm{yr}(2$ to $7.5 \mathrm{~m} / 100 \mathrm{Ka})$. Such accumulation rates in marine environments would equal or exceed interpreted rates of chert accumulation. Furthermore, dust deposition rates during the Pleistocene were at least two orders of magnitude greater than at present (Pye and Tsoar 1987). Such temporal variations in dust deposition in marine environments can account for the stratigraphy of bedded cherts where chert may form during periods of high dust input, but other lithologies (for example, shale, evaporites, or impure limestone) are deposited during periods of relatively low input of siliceous dust.

\section{Dust and upwelling as sources of silica and nutrients}

Although upwelling has been suggested as the source of silica for some chert (e.g., Hesse 1990), the offshore surface winds from modern warm-arid deserts that deposit dust in marine environments (Sarnthein and others, 1981; Goudie and Middleton 2001) commonly contribute to upwelling. As a result, both eolian dust and upwelling are plausible sources of nutrients and silica for chert offshore of warm arid highpressure belts. Although upwelling may serve as a source of dissolved silica for silica secreting organisms, dust also has the potential to supply both soluble silica for biogenic productivity as well as fine particles of $\alpha$-quartz that approximate the size of megaquartz in chert. Eolian processes, therefore, provide an alternative to upwelling as the source of silica for chert and nutrients for biological productivity, particularly in ancient epeiric seas. This observation is supported by data from Kolla and others,. (1981) who report greater than 30 percent biogenic opaline silica in recent carbonate-free sediment off the eastern coast of the Arabian Peninsula in an area known to receive significant amounts of dust (Gulf of Oman, Fig. 2). Areas of upwelling to the south in the Arabian Sea contain far less opaline silica.

Increases in silica concentrations in the world's oceans during Pleistocene glacial intervals have been documented and attributed to variations in the amount of silica supplied by rivers (Froelich and others, 1992). In contrast, Kurtz and Derry (1998) suggested that these Pleistocene variations in silica concentrations resulted from variations in the amount of eolian dust delivered from arid regions rather than variations in silica discharged from rivers. Kurtz and Derry (1998) further suggested that eolian dust might have been a significant and sometimes the predominant source of dissolved silica in the world's oceans. Evidence from the Pleistocene indicates, therefore, that the amount of modern dust delivered to the modern oceans is probably far less than that delivered during past periods of more pronounced aridity.

Conclusions.--- Copious influxes of dust to marine environments during periods of aridity in warm climates is likely to be conducive to the formation of bedded cherts, whereas humid periods limit or preclude eolian dust transport and chert formation. In addition, marine evaporative conditions associated with variations in the degree of aridity also may play an important role in silica equilibrium. Periods of highly evaporative conditions could trigger silica precipitation, probably as gels, along with evaporites, which may explain the common association of chert with evaporties. Furthermore, massive influxes of quartzose dust are likely to produce major increases in the productivity of silica-secreting organisms in response to increases in dissolved silica and nutrients. 


\section{Bedded Cherts and Warm-Arid Paleoclimates in North America: The Empirical Relation with Eolian Dust}

Among the numerous examples of bedded cherts occurring in strata that were deposited under warn-arid climatic conditions, five specific examples are briefly discussed herein. These examples include both shallow water epeiric sea and deep water trough depositional systems. Shallow epeiric sea examples include Early and early Middle Devonian cherts in the Appalachian Basin, Mississippian cherts across the North American craton, and unnamed Pennsylvanian cherts and cherty limestones in southeastern Nevada, USA. "Deep water" examples include the Devonian-Mississippian Arkansas Novaculite in the Ouachita Trough and Silurian-Mississippian Caballos Novaculite in the Marathon Basin. These five examples are highlighted in the context of the eolian dust model.

\section{Devonian shallow water cherts, Appalachian Basin}

Although deposition of Early and early Middle Devonian chert was widespread across North America (Dennison 1961), the Devonian shallow water example discussed herein is restricted to a stratigraphic interval that contains the Shriver Chert (basal unit), Oriskany Sandstone (middle unit), and Huntersville Chert (upper unit), and their stratigraphic equivalents in the Appalachian Basin. These strata extend from southwestern Virginia to central New York. At the time of chert deposition, the Appalachian Basin was in the vicinity of $30 \mathrm{E}$ to $40 \mathrm{E}$ S. latitude in a belt analogous to modern-day aridity and high pressure.

Paleoclimate indicators also suggest that the climate was arid (Scotese 1998). The Shriver Chert consists predominantly of decimeter-scale interbedded chert and silty limestone. The overlying Oriskany Sandstone contains rounded sand grains floating in a carbonate matrix and rounded to subrounded quartz grains in quartzarenite. Grabau $(1932,1940)$ and Cecil and others, (1991) proposed an eolian provenance for the Oriskany sand; the quartz sand was either blown into the carbonate environments of the Oriskany seaway or the sand was derived from ergs that were reworked during sea-level rise. Shinn (1973) has described a similar set of conditions in the modern Persian Gulf where dust and sand are blown into modern carbonate environments. The Huntersville Chert grades from impure chert in West Virginia into the cherty Onondaga Limestone in Pennsylvania and New York (Dennison 1961). Sheppard and Heald (1984) described the following seven lithotypes in the Huntersville Chert: (1) clean chert, (2) chert with organic material, (3) spicular chert, (4) dolomitic chert, (5) glauconitic chert, (6) silty argillaceous chert, and (7) dolomitic silty argillaceous chert. They pointed out that all lithotypes in the Huntersville contain some dolomite and siltsize (quartz) detritus.

Conclusions.--- The source of silica for the Shriver and Huntersville cherts (and equivalent cherty limestones) has previously been attributed to the biotic extraction of silica from seawater derived from the dissolution of volcanic ash (Dennison 1961; Sheppard and Heald 1984). Although minor amounts of biotic components have been recognized in the cherts, and volcanic ash (bentonite) occurs near the top of the Huntersville, the lithologies of the stratigraphic interval considered herein appear to be best explained by eolian sand and dust as the predominant source of silica. The coarsest silt fraction accounts for the quartz silt noted in the cherts as well as the quartz silt in interbedded limestone, whereas the finer size fraction of quartz dust readily provided an ample supply of soluble silica and residual particles that are equivalent in size to quartz crystallites in chert. Thus, the Early and early Middle Devonian sequence in the Appalachian Basin can be readily explained by temporal and spatial variations in eolian processes in a warm arid climate. In contrast, it is unclear how the enormous amounts of Devonian chert can be accounted for by either silica derived from dissolution of volcanic ash or biotic extraction of silica from normal seawater. 


\section{Mississippian shallow water cherts in the United States}

Relatively high sea level resulted in flooding of much of the North American craton during the late Osagean and early Meramecian (Mississippian) (Gutschick and Sandberg 1983) when aridity was widespread across the North American craton. Aridity is indicated by the presence of evaporites in Nova Scotia (Windsor Group), Appalachian Basin (Maccrady Formation), Michigan Basin (Michigan Formation), and the mid-continent (Burlington and Keokuk Limestones). The late Osage stage was also a period of significant chert deposition in epeiric sea (shelf) carbonates across the United States from the Appalachian Basin (Fort Payne Formation) in the east, through the mid-continent (Boone Formation), to the west (Redwall, Leadville, and Madison limestones). Seaman (2001) suggested that bedded chert in Redwall and equivalent limestone units in the Antler foreland basin in the western United States was precipitated by tectonically driven fluid flow throughout the Antler foreland basin. Other hypotheses have attributed late Osagean chert in epeiric seas to biogenic precipitation of silica contributed by upwelling (Gutschick and Sandberg 1983), and silica derived from volcanic ash. In contrast, Banks (1970) attributed the source of silica for syngenetic chert in dolostones within the Osagean Leadville Limestone in Colorado to dissolution of eolian sand (quartz). Carozzi (1993, p. 162) noted incidentally that silt-size eolian quartz dust should also be considered as a silica source for chert in the Leadville dolostone units.

Conclusions.--- The Osagean-Meramecian epeiric seas of North American were situated in an arid belt in the vicinity of 20E to 30E S. lat (Scotese 1998). Aridity is indicated by widespread occurrences of evaporites. The paleogeography of the time is consistent with atmospheric high pressure, an arid climate, and the export of large volumes of dust from exposed areas of aridity upwind of the chert-bearing OsageanMeramecian units. Thus, the primary source of the enormous quantities of silica contained in shallow water Osagean-Meramecian cherts appears to be better explained by an eolian source rather than by any of the other sources that are traditionally inferred.

\section{Pennsylvanian shallow water chert, southeastern Nevada}

Cecil and others, (2003) traced a Middle Pennsylvanian (Desmoinsian) cyclothem (fourth-order sequence) from the Appalachian Basin across the craton to southeastern Nevada (Arrow Canyon), where Pennsylvanian strata were deposited in a shallow-shelf environment inboard of the western margin of Pangea. Detailed investigations of the fourth-order sequence in Arrow Canyon revealed that a quartzose siltstone with calcite cement, interpreted as a continental dust deposit, overlies a paleoexposure surface (unconformity) that delineates the lower fourth-order sequence boundary (Cecil and others, 2003). The siltstone is overlain by transgressive cherty limestone and impure chert, which were interpreted as peritidal in origin. An open marine limestone with chert nodules overlies the cherty peritidal carbonates, and the open marine limestone is capped by a paleoexposure surface that represents the upper unconformable fourth-order sequence boundary. Fourth-order sequences are very repetitive in Arrow Canyon, with the lithology of each sequence varying primarily in the relative amounts of carbonate, quartzose silt, and chert. Bedded cherts and cherty limestones are the predominant lithology of the peritidal deposits in Arrow Canyon.

Interpreted paleowind directions (Parrish and Peterson 1988) in Pennsylvanian sand seas in Wyoming, Colorado, and Utah indicate that coeval strata in Arrow Canyon were deposited downwind. The paleowind directions suggest that these sand seas were the source of the silt in eolianite deposits that overlie the fourth-order order sequence boundaries (unconformities) in Arrow Canyon. Matrix-supported quartz silt in the peritidal carbonates indicates that the sand seas continued to supply eolian dust as sea level rose. Coarse silt was deposited further downwind during low stands in sea level, whereas finer particles were deposited in the Arrow Canyon region as sea level rose and as the margins of coeval sand seas were transgressed. 
Conclusions.--- Eolian dust appears to best explain the detrital quartz silt and silica contained within the Pennsylvanian siltstones, bedded cherts, impure limestones, and dolomites in Arrow Canyon where high pressure and aridity prevailed. In contrast, coeval paleosols (sequence boundaries), coal beds, and fluvial-deltaic siliciclastic sediments (Appalachian Basin) were deposited in the eastern United States in a belt of low atmospheric pressure and a humid climate (Cecil and others, 2003). These continentalscale observations are a further indication of the empirical correlation of bedded sedimentary chert with arid settings, atmospheric high pressure, and eolian dust.

\section{Devonian-Mississippian deepwater novaculites and cherts: Ouachita trough and Marathon Basin (Arkansas and Texas)}

Protracted periods of continental-scale deposition of cherts in shallow-water epeiric seas of North America occurred periodically over approximately $70 \mathrm{Ma}$ from the Late Silurian or Early Devonian into the Mississippian. During this time, the sediment starved Ouachita-Marathon structural trend was a center of deep-water deposition of silica from Arkansas to west-central Texas (e.g.,, McBride and Thomson 1970; Lowe 1989). Sediment starvation in the Ouachita trough has been attributed to aridity and the consequential restriction of fluvial sediment supply (Cecil and Edgar 1994; Edgar and Cecil 2003). The deepwater siliceous deposits are referred to as the Arkansas Novaculite in the Ouachita Trough and the Caballos Novaculite in the Marathon Basin.

Arkansas Novaculite.--- Lowe (1977) discussed the general stratigraphy of the Arkansas Novaculite as follows: a lower novaculite member, a middle impure chert member, and an upper novaculite member. The lower member is Devonian, the middle member spans the Devonian-Mississippian boundary, and the upper member is Mississippian. After noting the occurrence of silt-size quartz dispersed in all members, Lowe (1977) suggested that the silt was eolian in origin. He further noted that some of the silt grains appear to be partially assimilated into the chert or novaculite. This partial assimilation of coarse silt is a strong indication that the amorphous surface layer and the underlying disordered layer of quartz dust dissolved and served as a source of silica for chert-novaculite. Furthermore, the novaculite is thermodynamically stable relative to mechanically abraded quartz particles (Hemingway and others, 1991). Additional data from Hemingway and Nitkiewicz (1995) indicate that the authigenic $\alpha$-quartz should form diagenetically at the expense of both the surficial amorphous layer of silica and the underlying metastable disordered layer on eolian quartz silt. Lowe's observations are fully consistent with the thermodynamic data and an eolian origin for virtually all the silica in the Arkansas Novaculite.

Caballos Novaculite.--- McBride and Thomson (1970) provided a comprehensive review and summary of the various postulates regarding the origin of the Caballos Novaculite. They described five members of the Caballos from bottom to top as follows: (1) lower chert member, (2) lower novaculite member, (3) lower chert and shale member, (4) upper novaculite member, and (5) upper chert and shale member. They pointed out that the novaculite members are white and consist of nearly pure microquartz, similar to the Arkansas Novaculite, whereas the cherts and shales are variable in composition. They also noted that red shales in the chert members are the result of primary deposition of clay and unaltered iron oxide minerals. McBride and Thomson (1970) concluded that the Caballos is the product of biogenic precipitation, although they pointed out that it could not be demonstrated that more than 12 percent of the silica is the result of biotic processes.

Conclusions.--- In contrast to earlier postulates for the origin of the Arkansas and Caballos Novaculites, the petrology, stratigraphy (including coeval chert in epeiric sea deposits), paleogeography, and prevailing conditions of aridity are consistent with eolian dust as the source of silica. Dissolution of the metastable fine particles of eolian silica likely served as a source of silica in solution for radiolaria and sponges, whose siliceous remains are observed as a minor fraction of the silica in cherts and novaculites. Furthermore, temporal and spatial variations in the composition and particle size of eolian dust can account for the variations in lithologies within the deep-water novaculites and coeval shallow-water cherts. The 
nearly pure novaculite members suggest a sand sea provenance that was comprised predominantly of clean quartz sand, whereas the iron-bearing shales and cherts may have been derived from red deserts. However, direct evidence for eolian transport is lacking. The partially assimilated scattered grains of coarse silt currently only provide a proxy for eolian transport of silica. Other lines of evidence, such as isotopic signatures and rare earth element concentrations are likely masked or obliterated by sedimentation and diagenesis.

With more accurate age control on the various novaculite members, it should be possible to relate chert-novaculite lithologies to long-term climate variations. For example, it appears that deposition of the lower member of the Arkansas Novaculite was contemporaneous with the Devonian cherts and quartzarenites in the Appalachian Basin and elsewhere across the craton, whereas deposition of the middle member of the Arkansas Novaculite (impure chert and shale) was coeval with a pluvial event in the Appalachian Basin that spans the Late Devonian-Early Mississippian transition (Cecil and others, 1998; Cecil and others, 2002). The upper member of the Arkansas Novaculite is contemporaneous with chert deposition on the craton and the major Osagean-Meramecian period of aridity.

\section{Summary and Conclusions}

The general associations of Paleozoic cherts and cherty limestones in North American strata that were deposited within or near warm-arid climates appear to be too numerous to be purely coincidental. Although volcanic ash, volcanic vents, and upwelling may contribute to the origin of some sedimentary chert, these processes do not satisfactorily reconcile either the predominant source of silica (volume required) or the stratigraphy of most bedded sedimentary cherts. In contrast, the temporal and spatial distribution of the vast majority of bedded sedimentary cherts appears to be readily explained by dissolution, reprecipitation, and diagenesis of eolian dust. The enigmas of silica supply, chemistry of silica dissolution, and abiotic precipitation of silica are resolved with an eolian source of silica, the metastable portions of which will dissolve and reprecipitate in accordance with the thermodynamic properties of amorphous silica and quartz. Furthermore, dust is a cogent source of dissolved silica and nutrients for the production of biogenic silica.

In addition to the temporal and spatial association of bedded cherts with warm-arid paleoclimate settings, the experimental data of Whalley et al (1987) indicate that dissolution of massive influxes of eolian dust results in silica saturation or even supersaturation of seawater as well as sediment pore waters. Furthermore, the dissolved silica concentrations reported by Whalley et al (1987) far exceed silica concentrations in normal seawater, silica in upwelling waters, and dissolved silica delivered to the world's oceans by rivers, which rarely if ever exceeds the solubility of quartz. Quartzose dust, therefore, could have been the predominant source of silica for chert including biotic precipitates, abiotic precipitates of microquartz and fibrous silica, and residual fine-grained particles of $\alpha$-quartz (megaquartz).

As with all the other inferred sources of silica in chert, the warm-arid dust hypothesis may be equally difficult to prove. For example, primary oxygen isotope signatures of quartz dust are likely to be obscured by the complexity of reactions involved in dissolution, reprecipitation, and diagenesis of silica in aqueous environments. In addition, diagenesis and chert formation are also likely to obliterate much of the physical evidence for silica provenance and for eolian transport. In contrast, however, diagenetic alteration and chert formation may account for the paucity of demonstrable deposits of dust currently documented in marine strata.

Although the distribution of chert throughout the geologic record appears to be secular, individual occurrences probably recorded periodic influxes of dust. The periodicity is likely to be highly variable and range from relatively short-term, such as the cyclicity of chert beds in the Cretaceous chalks of Western Europe (e.g., Carozzi, 1993), to the very long-term deposition of the novaculites, as discussed above. Dust also may explain the source of silica for Precambrian cherts, particularly those associated with evaporites 
as described by Knauth (1994, p. 251-253). Although the dust hypothesis for the source of silica for bedded cherts is preliminary, it may have future geologic application in such diverse topics as paleoclimatology, paleooceanography, paleogeography, and in exploration for chert reservoirs containing hydrocarbons.

\section{Acknowledgments}

Critical reviews of early versions of the manuscript by Thomas Ahlbrandt, John Dennison, Milton Heald, Richard Larese, Earle McBride, Robert Ryder, John Slack, and Christopher Swezey are gratefully acknowledged.

\section{References}

Banks, N.G., 1970, Nature and origin of early and late cherts in the Leadville limestone, Colorado: Geological Society of America Bulletin, v. 81, no. 10, p. 3033-3048.

Cecil, C.B., Ahlbrandt, T.S., and Heald, M.T., 1991, Paleoclimate implications for the origin of Paleozoic quartz arenites in the Appalachian Basin: Geological Society of America Abstracts with Programs, v. 23, no. 5, p. A72.

Cecil, C.B., and Edgar, N.T., 1994, Climatic influence on basin sedimentation; application to the Ouachita Basin: in Cecil, C.B. and Edgar, N.T. eds., Predictive stratigraphic analysis; concept and application: U. S. Geological Survey Bulletin, Report: B 2110, p. 59-62.

Cecil, C.B., Brezinski, D.K., Dulong, F.T., 1998, Allocyclic controls on Paleozoic sedimentation in the central Appalachian Basin: US Geological Survey Open File Report 98-577, 75 p.

Cecil, C.B., Skema, V., Stamm, R., and Dulong, F.T., 2002, Evidence for Late Devonian and Early Carboniferous global cooling in the Appalachian basin: Geological Society of America Abstracts with Programs, v. 34, no. 7, p. 500.

Cecil, C.B., Dulong, F.T., West, R.R., Stamm, R., Wardlaw, B.R., and Edgar, N.T., 2003, Climate controls on the stratigraphy of a Middle Pennsylvanian cyclothem in North America, in Cecil, C.B. and Edgar, N.T. eds., Climate Controls on Stratigraphy: SEPM (Society for Sedimentary Geology) Special Publication 77, p. 151-180.

Carozzi, A.V., 1993, Sedimentary Petrology: Prentice Hall, Englewood Cliffs, New Jersey, 263 p.

Dennison, J.M., 1961, Stratigraphy of the Onesquethaw stage of Devonian in West Virginia and bordering states: West Virginia Geologic and Economic Survey Bulletin 22, $87 \mathrm{p}$.

Edgar, N.T., and Cecil, C.B., 2003, Influence of climate on deep-water sedimentation: application of a modern analogue to an ancient system: in Cecil, C.B. and Edgar, N.T. eds., Climate Controls on Stratigraphy: SEPM (Society for Sedimentary Geology) Special Publication 77, p. 185-191.

Froelich, P.N., Blanc, V., Mortlock, R.A., Chillrud, S.N., Dunstan, W., Udomkit, A., and Peng, T.-H., 1992, River fluxes of dissolved silica to the ocean were higher during glacials: $\mathrm{Ge} / \mathrm{Si}$ in diatoms, rivers, and oceans: Paleoceanography, v. 7, no. 6, p. 739-767.

Goudie, A.S., 2003, Great warm deserts of the world: Landscapes and evolution: New York, Oxford University Press Incorporated, $444 \mathrm{p}$.

Goudie, A.S. and Middleton, N.J., 2001, Saharan dust storms: Nature and consequences: Earth-Science Reviews, v. 56, p. 179-204.

Grabau, A. W., 1932, Principles of stratigraphy: New York, A.G. Seller, 1185 p.

Grabau, A. W., 1940, The rhythm of the ages: Peking, China,Henri Vetch, 561 p. 
Gutschick, R.C. and Sandberg, C.A., 1983, Mississippian continental margins of the conterminous United States: SEPM (Society for Sedimentary Geology) Special Publication 33, p. 79-96.

Haught, O.L., 1956, Probabilities of presence of reservoirs in the Cambrian and Ordovician of the Allegheny synclinorium: Kentucky Geological Survey, Series 9, Special Publication 9, p. 7-15.

Hemingway, B.S. and Nitkiewicz, A., 1995, Variation of the enthalpy of solution of quartz in aqueous HF as a function of sample particle size: U.S. Geological Survey Open-File Report 95-510, 5 p.

Hemingway, B.S., Robie, R.A., Evans, H.T., Jr., and Kerrick, D.M., 1991, Heat capacities and entropies of sillimanite, fibrolite, andalusite, kyanite, and quartz and the $\mathrm{Al}_{2} \mathrm{O}_{5}$ phase diagram: American Mineralogist, v. 76, p. 15971613.

Hesse, R., 1990, Origin of chert and silica diagenesis, in Mcllreath, I.A., and Morrow, D.W., eds, Diagenesis: Geological Association of Canada, Geoscience Canada, Reprint Series 4, p. 227-275.

Iller, R.K., 1955, The colloidal chemistry of silica and silicates: Ithica, N.Y., Cornell University Press, 324 p.

Kolla, V., Pulak, K.R., and Kostecki, J.A., 1981, Surficial sediments of the Arabian Sea: Marine Geology, v. 41, p. 183-204.

Knauth, L.P., 1994, Petrogenesis of chert, in Heaney, P.T., Prewitt, C.T., and Gibbs, G.V., eds., Silica: physical behavior, geochemistry, and materials application: Mineralogical Society of America Reviews in Mineralogy, v. 29, p. 233-258.

Kronenberg, A.K., 1994, Hydrogen speciation and chemical weakening of quartz, in Heaney, P.T., Prewitt, C.T., and Gibbs, G.V. eds., Silica: physical behavior, geochemistry, and materials application: Mineralogical Society of America Reviews in Mineralogy, v. 29, p.123-176.

Kurtz, A.C., and Derry, L.A., 1998, Mineral aerosols and the marine silica cycle: Constraints from Ge/Si: Geological Society of America Abstracts with Programs, v. 30, no. 7, p. 99.

Lowe, D.R., 1977, The Arkansas Novaculite; some aspects of its physical sedimentation: in Stone, C.G., ed., Symposium on the Geology of the Ouachita Mountains, v. 1, Stratigraphy, sedimentology, petrology, tectonics, and paleontology, Arkansas Geological Commission, Little Rock, Arkansas, USA, p. 132-138.

Lowe, D.R., 1989, Stratigraphy, sedimentation, and depositional setting of pre-orogenic rocks of the Ouachita Mountains, Arkansas and Oklahoma, in Hatcher, R.D., Jr., Thomas, W.H., and Viele, G.W., eds., The Appalachian-Ouachita orogen in the United States v. F-2 of the Geology of North America, Boulder, CO, Geological Society of America, p. 575-590.

McBride, E.F., and Thomson, A., 1970, The Caballos novaculite, Marathon region, Texas: Geological Society of America Special Paper 122, $129 \mathrm{p}$.

Molinaroli, L., 1996, Mineralogical characteristics of Saharan dust with a view toward its final destination in Mediterranean sediments: in Guerzoni, S., and Chester, R., eds., The impact of desert dust across the Mediterranean: Dordrecht, Netherlands, Kluwer Academic Publishers, p. 153-162.

Parrish, J.T., and Peterson, F., 1988, Wind directions predicted from global circulation models and wind directions determined from eolian sandstones of the western United States\&A comparison: Sedimentary Geology, v. 56, p. 261-282.

Pye, K., and Tsoar, H., 1987, The mechanics and geological implications of dust transport and deposition in deserts with particular reference to loess formation and dune sand diagenesis in the northern Negev, Israel, in Frostick, L. and Reid, l., eds., Desert sediments: Ancient and modern: Geological Society [London] Special Publication no 35 , p. 139-156.

Renton, J.J., Heald, M.T., and Cecil, C.B., 1969, Experimental investigation of pressure solution of quartz: Journal of Sedimentary Petrology, v. 39, p. 1107-1117.

Sarnthein, M., Tetzlaff, G., Koopman, B.F, Wolter, K., and Pflaumann, U., 1981, Glacial and interglacial wind regimes over the eastern subtropical Atlantic and north-west Africa: Nature, v. 293, p. 193-196.

Scotese, C. R., 1998, Quicktime Computer Animations, PALEOMAP Project: Department of Geology, University of Texas at Arlington, Arlington, Texas.

Seaman, T.L., 2001, Extensive Mississippian bedded chert in the Antler foreland basin; silicification due to tectonically driven subsurface flow: Geological Society of America Abstracts with Programs, v. 33, no 3, p. 83.

Sheppard, S.J. and Heald, M.T., 1984, Petrology of the Huntersville Chert: Southeastern Geology, v. 25, no 1, p. 37-47.

Whalley, W.B., Smith, B.J., McAlister, J.J., and Edwards, A.J., 1987, Eolian abrasion of quartz particles and the production of silt-size fragments: Preliminary results, in Frostick, L., and Reid, I., eds., Desert sediments: Ancient and modern: Geological Society [London] Special Publication 35, p. 129-138. 
Wright, J., 2001, Making loess-sized quartz silt: Data from laboratory simulations and implications for sediment transport pathways and the formation of "desert" loess deposits associated with the Sahara: Quaternary International, v. 76/77, p. 7-19. 


\section{Figure captions}

Figure 1. - Diagrammatic cross section of an angular silt-sized grain of quartz analogous to the maximum grain size in aerosols. Eolian abrasion induces silica structures that progressively grade inward as follows: 1) an outer amorphous layer, 2) an underlying structurally disordered layer, 3) an ordered core of $\alpha$-quartz.

Figure 2. - Northeasterly winds from Iran and Pakistan transport dust plums over the eastern Persian Gulf (left center), Gulf of Oman (lower center) and northern Arabian Sea (lower right) (photo credit: Jeff Schmaltz, MODIS Rapid Response Team, NASA/GSFC 11-16-2003). Periodically, winds from the west and southwest also bring dust from the Arabian Peninsula to the Persian Gulf, Gulf of Oman, and the northern part of the Arabian Sea. 


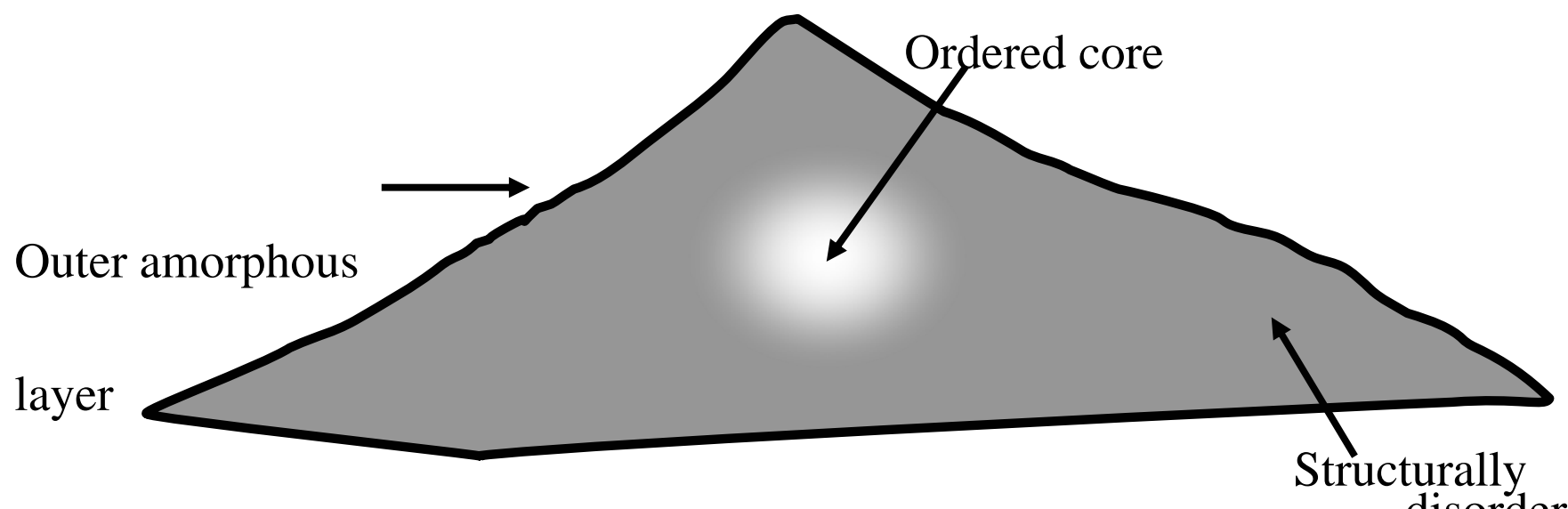

disordered layer

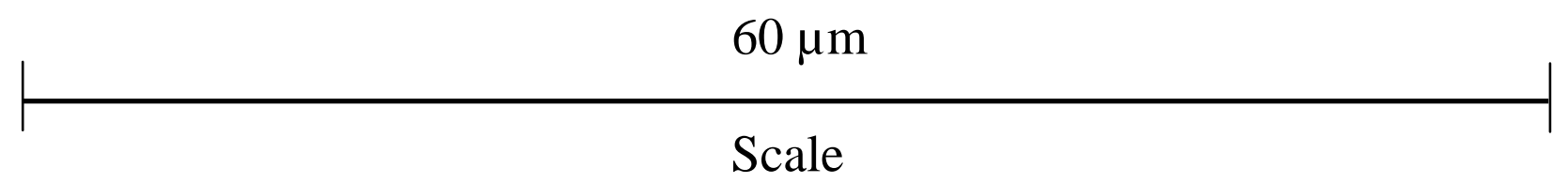




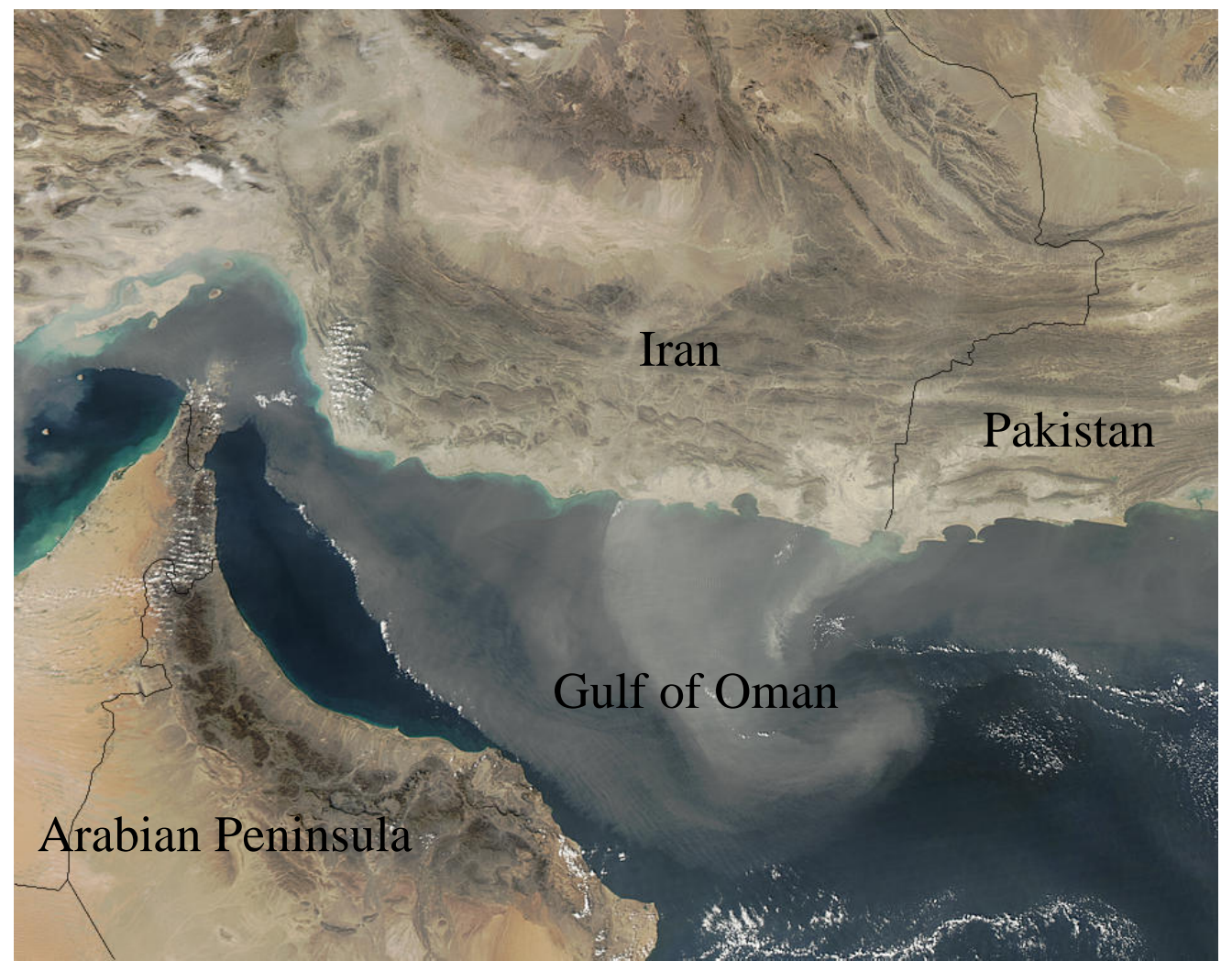

